\title{
Наука и инновации в исследовании биоразнообразия растительного мира Байкальской Сибири
}

\section{Science and innovations in the research of a biodiversity of the plant world of the Baikal Siberia}

\author{
Намзалов Б. Б. \\ Namzalov B. B. \\ Бурятский государственный университет, г. Улан-Удэ, Россия. E-mail: namzalov@rambler.ru \\ Buryat State University, Ulan-Ude, Russia
}

Peферат. Растительный мир Байкальской Сибири (БС) сформировался на стыке нескольких биогеографических провинций Северной и Центральной Азии и характеризуется богатством биоразнообразия. Флора Бурятии как часть БС включает 2206 видов сосудистых растений (610 родов и 136 семейств). Из них в Красную книгу РБ включены 158 видов, что составляет 7,2%. В горных долинах Прибайкалья и Забайкалья выявлены очаги новейшего эндемизма. Помимо эндемиков характерны реликты, из них к древнейшим плиоценовым относится 27 видов. В рамках инновационных программ исследования создана система мониторинга за состоянием лесов Байкальского побережья, уникальными популяциями редких растений. В основе ее лежит центр АПИК (атмосферно-почвенный измерительный комплекс) для мониторинга за состоянием среды, что позволяет составить «паспорт» биоразнообразия экосистем. Практические разработки позволили расширить ассортимент полезных растений (пищевые, лекарственные, кормовые и др.) из природной флоры, а также выявить долю социально опасных и вредных (наркотических, сорных, ядовитых) растений в растительности БС, Бурятии.

Ключевые слова. Бурятия, растительность, редкие виды, флора, экологический мониторинг, эндемизм и реликтовость.

Summary. The plant sphere of the Baikal Siberia (BS) was created on a junction of several biogeographical provinces of Northern and Central Asia and is characterized by richness of a biodiversity. Flora of Buryatia as a part of BS includes 2206 species of vascular plants (610 genus and 136 families). From them 158 species that makes $7.2 \%$ are included into the Red List of RB. In mountain valleys of Baikal region and Transbaikalia the centers of the latest endemism are revealed. Besides endemics relicts are characterized, from them 27 species belong to the most ancient Pliocene. As part of innovative research programs, a monitoring system of conditions of the forests on the Baikal coast and unique populations of rare plants is created.The APIK (atmospheric and soil measuring complex) center for monitoring of a condition of the environment is the cornerstone of it that allows to make "passport" of a biodiversity of ecosystems. Practical developments allowed to expand the range of the useful plants (food, medicinal, fodder, etc.) from natural flora and to reveal a share of social and dangerous and harmful (narcotic, weed, poisonous) plants in vegetation of BS, Buryatia.

Key words. Buryatia, vegetation, rare species, flora, ecological monitoring, endemism and relictism.

\section{Природные феномены территории}

«Биоразнообразие» нередко ассоциируется с внешним многообразием, или варьированием форм, размеров или поведения живых существ. С более общей, методологической точки зрения, биоразнообразие не может быть сведено только к внешним формам варьирования жизни. Правомерно говорить о генетическом, таксономическом, ценотическом и экосистемном уровнях биоразнообразия.

Растительный мир Байкальской Сибири (БС) сформировался на стыке нескольких биогеографических провинций Северной и Центральной Азии и характеризуется разнообразием и контрастностью сочетания растительных сообществ разных типов - от горных тундр, альпийских лугов и мерзлотных ландшафтов тайги до сухих и опустыненных степей. 
Флора Бурятии, являясь ключевой и центральной частью территории БС, включает 2206 видов сосудистых растений, представляющих 610 родов из 136 семейств (Определитель..., 2001). Из этого многообразия в Красную книгу Республики Бурятии занесены 158 видов - около 7,2 \% от общего числа видов (Красная книга ..., 2013). В горных долинах Прибайкалья и Забайкалья выявлены очаги новейшего эндемизма - Байкальский фитогеографический узел (Тайсаев, 2002; Намзалов, 2009). Только во флоре степей Байкальской Сибири известно 48 видов-эндемиков, это 7,0 \% общего состава флоры (Пешкова, 1984). Помимо эндемиков в степных экосистемах характерны реликты, из них к древнейшим плиоценовым относится 27 видов (Намзалов, 2012). Реликтовые растения, сохранившиеся от прошлых геологических эпох, встречаются в локальных убежищах - рефугиях, очень чувствительны к изменениям природного окружения.

Реликтовые виды, так же, как и эндемичные, нигде не выходят на доминирующее положение в ландшафтах Забайкалья. Часто они приурочены к каменистым склонам останцев, сложенным древнейшими (палеозойскими) гранитоидами, палеогеновыми карбонатными отложениями.

\section{Обоснование исследований}

Необходимость научных исследований в области биоразнообразия растительного мира Республики Бурятии (РБ) и в целом Байкальской Сибири (БС) определяется следующими обстоятельствами:

- территория БС, как и Бурятия, относится к числу наиболее богатых по разнообразию растительности территорий Сибири, связанной особым географическим положением на стыке Северной и Внутренней Азии, и Байкальской рифтовой зоне - крупнейшему тектоническому району страны;

- по размерам возможного потенциального ущерба, связанная потерями гено- и ценофонда биоразнообразия, Бурятия входит в число 7 регионов среди 35, находящихся в поясе древнего и современного горообразования России. Это Алтай, Хакасия, Тыва, Якутия, Прибайкалье и Забайкальский край;

- для территории БС, Бурятии свойственны опасные экзогенные процессы (обвалы, оползни, сели и др.), которые в сочетании сейсмическими процессами (развитие зон затопления и наводнения) могут привести к непредвиденным потерям генофонда биоразнообразия, особенно ее уникальному компоненту - эндемикам и реликтам;

• придание оз. Байкал статуса участка Всемирного наследия определило критерии устойчивого развития региона, и это предполагает сохранение биоразнообразия природных экосистем и устойчивое использование биологических ресурсов Байкальской Сибири и Бурятии, ее растительного мира. Это, прежде всего, предполагает:

- сохранение биоразнообразия природных экосистем;

- устойчивое использование биологических ресурсов БС Бурятии, ее растительного мира.

\section{Направления и задачи исследований}

1. Научные исследования направлены на приоритетные направления в области сохранения биоразнообразия экосистем на территории БС, РБ (редкие растения, уникальные сообщества и рефугии эндемичных и реликтовых видов).

Это включает:

- выявление генофонда редких видов растений, анализ состояния их популяций и сообществ с их участием, а также уникальных ландшафтов, что должно стать основанием при определении необходимых работ и формировании перечня первоочередных объектов растительного мира региона для охраны и мониторинга;

• проведение научно-исследовательских работ позволит сформировать единые подходы по выявлению и оценке состояния уникальных компонентов биоты, степени риска потери генофонда и выработки мер защиты сохранения биоразнообразия территории, в частности растительности БС.

\section{Решаемые задачи:}

1. Развитие системы экологического мониторинга уникальных популяций, биоценозов и рефугиев растительного мира Бурятии (Байкал и Прибайкалье, Восточный Саян с Тункинской долиной, Южная и Центральная Бурятия - Селенгинское среднегорье, Северная Бурятия и т.д.). 
2. Уточнение исходной базы разнообразия растительности и составление новых карт флористического микрорайонирования, центров и очагов локального биоразнообразия как для отдельных природных урочищ, так и районов Бурятии (Джида, долины Уды, Иволгинская котловина, Кяхта, Северобайкальск, дельта Селенги, Горная Ока и др.)

3. Помимо комплексных исследований растительного мира Бурятии, выполняются прикладные (инновационные) разработки, которые связаны с выявлением ресурсов кормовых растений и пастбищных угодий, лекарственных, пищевых и иных полезных растений. Эти исследования были поддержаны международными, Федеральными и Республиканскими грантами (ГЭФ, Nature fond, РФФИ, РГНФ, МОиН РФ, Министерства природных ресурсов РБ, Министерства МОиН РБ).

В целом, результаты инновационных разработок следующие:

I. В 2007 и 2009 гг. завершены проекты РГНФ «Комплексное социально-экологическое исследование особенностей номадного природопользования аборигенных этносов горных районов Южной Сибири». В работе участвовали ведущие специалисты БГУ, ТывГУ, БИП СО РАН. Проведено обобщение современных проблем этноэкологии и традиционного природопользования, создана база данных по этноботанике в формате современных ГИС-технологий. Проведены региональные, всероссийские и международные конференции по обозначенной проблеме.

II. В рамках проекта впервые был издан фундаментальный труд в области традиционной медицины «Этноботанические исследования. Справочник растений бурятской народной медицины» (Намзалов, Басхаева, 2008). Уникальный свод целебных растений на 5 языках уже дает результаты в поиске новых лекарственных растений, разработки перспективных фитопрепаратов (Анцупова и др., 2015).

III. Создан центр долгосрочного экологического мониторинга модельных прибрежных лесов Байкала и паспортизация эталонных экосистем центральной зоны Байкальской природной территории. Специально для высокочувствительного экологического мониторинга состояния таежных, лугово-болотных экосистем Прибайкалья создан центр АПИК (атмосферно-почвенный измерительный комплекс) вблизи населенных пунктов Максимиха и Горячинск совместно с Институтом мониторинга климатических и экологических систем ИМКЭС СО РАН, Томск (директор - Крутиков В. А.). Центр генерирует информацию с сети реперных точек, установленных на разных типах экосистем таежного Прибайкалья; в сети передача данных осуществляется через встроенный модем посредством сотовой связи, что позволяет контролировать процесс в режиме реального времени.

IV. За последние два десятилетия по проблеме «Растительность Байкальского региона и сопредельных территорий» проведены 6 всероссийских и международных конференций $(1998,2001,2005$, $2011,2013,2016)$, некоторые из них совместно с Институтом общей и экспериментальной биологии СО РАН. В результате создана богатейшая информация о современном разнообразии растительного мира территории, результаты исследований обобщены в региональных сводках по Бурятии.

Шестая конференция прошла 21-22 ноября 2016 г. в статусе всероссийского семинара с международным участием и была посвящена уникальному компоненту растительности Бурятии - эндемичным и реликтовым растениям Забайкалья. Тематика семинара соответствовала задачам инициативного научного проекта, поддержанного грантом РФФИ и Правительством Республики Бурятии «Реликтовые и эндемичные растения Забайкалья: анализ состояния популяций, экологическое картирование рефугиев и перспективы сохранения генофонда (№ 15-44-04112, 2015-2017 гг.)». В рамках проекта разрабатана программа создания, нового и не имеющего аналогов в регионе труда - «Атлас редких растений и фитоценозов, уникальных ландшафтов Забайкалья». В атласе при характеристике редких видов в соответствии концепции биоразнообразия будет дано их целостное рассмотрение в растительном мире. Это означает раскрытие данного феномена не только на видовом, но и ценотическом и ландшафтном (экосистемном) уровнях (Намзалов, 2016). 
В целом, тематики научных исследований направлены на сохранение биоразнообразия растительного мира на территории РБ. Необходимо формирование территориальной системы контроля биоразнообразия и осуществление мониторинга устойчивости популяций редких видов и уникальных экосистем региона.

\section{Заключение}

Таким образом, Бурятским государственным университетом в лице кафедры ботаники с 2016 г. внедрена современная система мониторинга за состоянием эталонных лесов Байкальского побережья, уникальными популяциями редких реликтовых и эндемичных растений. На сегодня инструментальные методы диагностики являются надежным средством защиты и прогноза в мире живой природы. В основе ее лежит разработанный томскими учеными метод АПИК для целей непрерывного мониторинга за состоянием среды (температурно-влажностные градиенты) в почве и атмосфере, что позволяет составить «паспорт» состояния экосистем и устойчивости биоразнообразия.

Внедряемые практические разработки позволят расширить ассортимент полезных растений (пищевые, лекарственные, кормовые и др.) из природной флоры, а также выявить долю социально опасных и вредных (наркотических, сорных, ядовитых) растений в растительности БС, Бурятии. Эти практические разработки должны быть реализованы в ходе выполнения особых проектов:

1. Создание труда - «Атлас редких растений и фитоценозов, уникальных ландшафтов Забайкалья».

2. Подготовка фундаментальных сводок: Атлас «Растения бурятской народной медицины»; справочник-каталог «Сорные и ядовитые растения Бурятии».

Благодарности. Исследования проведены при поддержке грантов - РФФИ № 15-44-04112 и БГУ № 19-10-0502

\section{ЛИТЕРАТУРА}

Анцупова Т. П., Дашиева Ж. Д., Ендонова Г. Б., Жапова О. И., Ильина Л. П., Павлова Е. П. Лекарственные растения Бурятии в науке и практике: монография. - Улан-Удэ: Изд-во ВСГУТУ, 2015. - 150 с.

Красная книга Республики Бурятия: Редкие и находящиеся под угрозой исчезновения виды животных, растений и грибов. - Изд. 3-е, перераб. и доп. / отв. ред. Н. М. Пронин. - Улан-Удэ: Изд-во БНЦ СО РАН, 2013. - 688 с.

Намзалов Б. Б. Байкальский фитогеографический узел как новейший центр эндемизма Внутренней Азии // Сибирский экологический журнал, 2009. - № 4. - С. 563-571.

Намзалов Б. Б. К вопросу о реликтах во флоре и растительности степных экосистем Байкальской Сибири // Растительный мир Азиатской России, 2012. - № 2 (10). - С. 94-100.

Намзалов Б. Б. О концепции атласа редких растений и фитоценозов, уникальных ландшафтов Забайкалья // Вестник БГУ. Сер. Биология. География: Матер. Всеросс. науч.-практ. семинара «Редкие растения и фитоценозы Байкальского региона и сопредельных территорий (21-22 ноября 2016, г. Улан-Удэ). - Вып. 2-3/2016. - С. 3-18.

Намзалов Б. Б., Басхаева Т. Г. Этноботанические исследования. Справочник растений бурятской народной медицины. - Улан-Удэ: Изд-во Бурят. госуниверситета, 2008. - 183 с.

Определитель растений Бурятии / под ред. О. А. Аненхонова. - Улан-Удэ, 2001. - 670 с.

Пешкова Г. А. О сопряженности в развитии мезофильных и ксерофильных флор Байкальской Сибири в кайнозое // История растительного покрова Северной Азии. Новосибирск: Наука, Сиб. отд-ние, 1984. C. $144-156$.

Taйсаев T. T. Ландшафтно-геохимический фактор биоразнообразия и особенности традиционного природопользования горных экосистем // Сибирский экологический журнал, 2002. - № 5. - С. 617-624. 